\author{
Original Article
}

\title{
Momordica charantia L. extracts against Aedes aegypti larvae
}

\author{
Extratos de Momordica charantia L. sobre larvas de Aedes aegypti
}

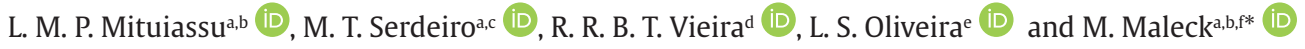 \\ aUniversidade de Vassouras, Laboratório de Insetos Vetores, Vassouras, RJ, Brasil \\ bUniversidade de Vassouras, Mestrado Profissional em Ciências Ambientais, Vassouras, RJ, Brasil \\ 'Fundação Oswaldo Cruz - FIOCRUZ, Instituto Oswaldo Cruz - IOC, Laboratório Interdisciplinar de Vigilância Entomológica em Diptera e \\ Hemiptera, Rio de Janeiro, RJ, Brasil \\ dFundação Educacional Dom André Arcoverde, Faculdade de Medicina de Valença, Centro de Ensino Superior de Valença, Valença, RJ, Brasil \\ eUniversidade de Vassouras, Pró-Reitoria de Ciências da Saúde, Vassouras, RJ, Brasil \\ fFundação Oswaldo Cruz - FIOCRUZ, Instituto Oswaldo Cruz - IOC, Laboratório de Entomologia Médica e Forense, Rio de Janeiro, RJ, Brasil
}

\begin{abstract}
Mormodica charantia (Curcubitaceae) is a plant with great medicinal potential, also used as an alternative of mosquitoes control as demonstrated by previous studies. We evaluated the larvicidal activity of crude extracts of ethyl acetate, methanol and hexane from flowers and fruits of $M$. charantia against Aedes aegypti (Culicidae). Flowers and fruits were macerated in methanol, ethyl acetate and hexane. Bioassays were performed with application of the extracts at final concentrations of $1-200 \mu \mathrm{g} / \mathrm{mL}$ in the middle of the third instar larvae of A. aegypti (L3). The results showed high toxicity to ethyl acetate extracts from flowers and fruits at concentrations of $200 \mu \mathrm{g} / \mathrm{mL}$ and $100 \mu \mathrm{g} / \mathrm{mL}$, with $97 \%$ and $87 \%$ of larvae mortality (L3), respectively. Hexane extract demonstrated low toxicity, while methanol extract exhibited $78 \%$ larval mortality. The data suggested that the ethyl acetate extracts of flowers and fruits of $M$. charantia can effectively contribute to larvicidal activity. In addition, purification of $M$. charantia extracts may lead to a promising larvicidal activity to control the A. aegypti population.
\end{abstract}

Keywords: larval mortality, control population, larvicidal activity, Curcubitaceae, Culicidae.

\begin{abstract}
Resumo
Mormodica charantia (Curcubitaceae) é uma planta com grande potencial medicinal, sendo também uma alternativa no controle de mosquitos conforme demonstrado por estudos prévios. Avaliou-se a atividade larvicida dos extratos brutos de acetato de etila, metanólico e hexânico das folhas, flores e frutos de $M$. charantia no Aedes aegypti (Culicidae). Folhas, flores e frutos foram macerados em metanol, acetato de etila e hexano. Os bioensaios foram realizados com aplicação dos extratos nas concentrações finais de $1-200 \mu \mathrm{g} / \mathrm{mL}$ no meio de criação das larvas de terceiro estádio de $A$. aegypti (L3). Os resultados obtidos apontaram alta toxicidade para os extratos de acetato de etila das flores e frutos nas concentrações de $200 \mu \mathrm{g} / \mathrm{mL}$ e $100 \mu \mathrm{g} / \mathrm{mL}$ com mortalidade em L3 de 96,7\% e 87\%, respectivamente. Baixa toxicidade para o extrato hexânico e o extrato metanólico apresentou mortalidade de 78\% larval. Os dados sugerem que os extratos de acetato de etila das flores e frutos de $M$. charantia podem contribuir efetivamente para atividade larvicida no controle da população de A. aegypti.
\end{abstract}

Palavras-chave: mortalidade larval, controle da população, atividade larvicida, Curcubitaceae, Culicidae.

\section{Introduction}

Plants are a rich source of chemical bioactive compounds that can act towards insect control. The diversity of Brazilian flora presents immense potential for compounds that can act as insecticides (Bezerra et al., 2014). Traditional knowledge of the use and efficacy of plants has contributed significantly to the learning of their properties, which has attracted interest among researchers in several fields of study (Dutra et al., 2016). The plant species Momordica charantia L., of the family Cucurbitaceae, is widely farmed in tropical and subtropical countries. M. charantia is of African origin and can be found in several countries, including
Brazil, where it has become popular under the names Melão-de-São-Caetano, Erva de lavadeira, Fruto de cobra and Erva de São Vicente, among others (Zocoler et al., 2006).

It is known as a traditional medicinal fruit and represents an alternative for studies on controlling disease-causing vectors, since this plant presents a range of therapeutic properties, including anticancer, antiviral, anti-inflammatory, hypoglycemic, antimalarial and other activities (Jia et al., 2017). Moreover, this species has shown larvicide activity against three species of mosquitos: Anopheles stephensi (Liston, 1901),

*e-mail: marise.maleck@gmail.com

Received: April 12, 2020 - Accepted: June 19, 2020

This is an Open Access article distributed under the terms of the Creative Commons Attribution License, which permits unrestricted use, distribution, and reproduction in any medium, provided the original work is properly cited. 
Culex quinquefasciatus (Say, 1823) and Aedes aegypti (Linnaeus, 1762) (Singh et al., 2006; Pari et al., 2020).

With the increasing epidemic cases of dengue fever, chikungunya and zika, the A. aegypti mosquito has become an important public health issue, since it presents the greatest dispersion in urban areas of the world (Gould et al., 2017). Moreover, this species is the main vector of the viruses which cause these diseases (Gould et al., 2017). Several factors have promoted recurrence of dengue epidemics and other diseases transmitted by $A$. aegypti, such as the proliferation of mosquitoes, rapid demographic growth associated with intensive and disorganized urbanization and inadequate infrastructure, among other factors (Mendonça et al., 2009).

Efforts toward the prevention of arboviral diseases transmitted by the A. aegypti mosquito are aimed at the reduction of vector density through epidemiological surveillance and vector-control strategies (Brasil, 2009). Although it is recognize the importance of social participation and community involvement to avoid high levels of insect infestation, the chemical control is an important strategy in endemic areas that can be accomplished through the application of chemical pesticides (larvicides and insecticides) (Brasil, 2009). However, the indiscriminate overuse of those pesticides gradually increases the ability of the A. aegypti mosquito to tolerate synthetic chemical insecticides, impairing their effectiveness (Naqqash et al., 2016).This is a factor that associated with the need for less toxic products for both human health and the environment, increases the interest for exploring new approaches to higher effectiveness in the control of A. aegypti (Pavela, 2016; Benelli, 2018; Muangmoon et al., 2018).

Rahuman and Venkatesan (2008) highlight that plant extracts and essential oils can indeed be alternative sources for controlling mosquito larvae, as well as constituting a rich source of bioactive and biodegradable compounds into a nontoxic product potentially suitable for use in mosquito larvae control.

Plants offer an extraordinary diversity of metabolites with proven efficacy against insects of medical and veterinary importance, as well as other insect species considered agricultural pests (Formentini et al., 2016; Panchal and Tiwari, 2017; Spochacz et al., 2018; Cruz et al., 2019).

Thus, insecticidal plant extracts have emerged as a subject of study and have been evaluated as an alternative for integrated management of crop pests. They may also be a good alternative for controlling vectors of diseases (Pavela, 2016).

The present study contributes to a promissing alternative for combating the causative agent of urban yellow fever, dengue fever, chikungunya and zika through the use of M. charantia extracts. This plant has gained great importance due to its medicinal properties, which has led to the need for further studies assessing additional benefits, such as the action of $M$. charantia leaf, fruit and flower extracts on the larvae of $A$. aegypti.

\section{Material and Methods}

\subsection{Botanical material}

Mormodica charantia was collected in the municipality of Valença, state of Rio de Janeiro, southeastern Brazil (22 $14^{\prime}$ ' 44" S; $\left.43^{\circ} 42^{\prime} 01^{\prime \prime} \mathrm{W}\right)$, which is at an altitude of $560 \mathrm{~m}$ and covers an area of $1308.1 \mathrm{~km}^{2}$. The botanical voucher was collected during the mornings of the months of October and December 2015.

The botanical voucher was identified by Dr. Ana Carla Pinheiro Lima, and the sample was deposited in the herbarium of the University of Vassouras, Vassouras, Rio de Janeiro, Brazil, registered under the number HUSSCUR001.

\subsection{Extraction}

Flowers and fruits (EFF) of $M$. charantia were used in combination to obtain the plant extracts. The plant material was washed with distilled water and dried at room temperature. After drying, the material was fragmented and then ground to prepare the extracts. The flowers and fruits ( $74 \mathrm{~g}$ ) were macerated together using the following solvents of increasing polarity: hexane (Isofar) $(400 \mathrm{~mL})$, ethyl acetate (Quimex) (400 mL) and methanol (Vetec) (400 mL; 1:1). Thus, hexane, ethyl acetate and methanol extracts were obtained, respectively. All the materials were prepared in dark-glass flasks, with occasional agitation twice a week for a period of 20 days. After maceration, the extracts were filtered and concentrated in a rotary evaporator, under reduced pressure at $40^{\circ} \mathrm{C}$. The product was then stored in a dark glass flask and placed in a fridge at $12^{\circ} \mathrm{C}$ and $25 \%$ relative humidity $(\mathrm{RH})$.

\subsection{Bioassays}

A. aegypti eggs were obtained from the Sentinel Operational Unit of Mosquito Vectors (Nosmove), Oswaldo Cruz Institute, FIOCRUZ, Rio de Janeiro, Brazil. Bioassays were conducted at the Vector Insect Laboratory, University of Vassouras, Vassouras, Rio de Janeiro, Brazil. For these tests, the eggs were analyzed regarding their viability and placed for hatching in containers filled with mineral water previously heated to $28^{\circ} \mathrm{C}$, and then fish feed was added (Alcon Guppy ${ }^{\circledR}$ ). The containers with the eggs were kept in a biochemical oxygen demand (BOD) climatized chamber at $27 \pm 1{ }^{\circ} \mathrm{C}$ and $70 \pm 10 \% \mathrm{RH}$. After hatching, the thirdstage larvae (L3) were separated to perform the bioassays.

The hexane (HEX), ethyl acetate (AcOEt) and methanol (MeOH) crude extracts (EFF) were diluted with dimethyl sulfoxide (DMSO) in the following proportions: HEX: DMSO (1:3), AcOEt: DMSO (1:3) and $\mathrm{MeOH}$ : DMSO (1:3), respectively, obtaining final concentrations of $1,10,50,100$ and $200 \mu \mathrm{g} / \mathrm{mL}$. Subsequently, these solutions were applied ( $\mu \mathrm{L}: \mathrm{mL})$ to the larval rearing environment in glass containers containing mineral water $(20 \mathrm{~mL})$ in a ratio of $1: 1$.

Bioassays were conducted on 20 third-stage larvae (L3) per testing group and on a control group (without substance and dilution solvent), including also a witness control group (without substance and with dilution solvent). The experiments were performed in triplicate 
(R1, R2 and R3), thereby totaling 60 larvae per group, with three repetitions. After this procedure, the insects received a normal diet ( $0.3 \mathrm{mg}$ fish feed for each larva) and were kept in a BOD climatized chamber at $27 \pm 1{ }^{\circ} \mathrm{C}$ and $70 \pm 10 \% \mathrm{RH}$. They were observed for 25 days with respect to development and mortality. Bioassays were conducted according to the methodology of Maleck et al. (2013), adapted from WHO (2005).

\subsection{Statistical analysis}

The biological bioassay results were subjected to the Tukey test using GraphPad Prism version 6.0. One-criterion analysis of variance (ANOVA) was also applied, and this was considered significant for $\mathrm{P}<0.01$ (Sokal and Rohlf, 1979). Standard deviation was calculated based on the mean values of the experiments. The statistical analysis to calculate $\mathrm{LC}_{50}$ followed the trimmed Spearman-Karber methodology (Hamilton et al., 1977).

\section{Results}

Extraction from the flowers and fruits (EFF) of M. charantia yielded $330 \mathrm{mg}$ of AcOEt extract, $290 \mathrm{mg}$ of $\mathrm{MeOH}$ extract and $42 \mathrm{mg}$ of HEX extract.

The AcOEt extract used at a concentration of $100 \mu \mathrm{g} / \mathrm{mL}$ demonstrated behavioral alterations among larvae, with low mobility and lethargy within 24 hours of larval treatment (L3). Concerning the mosquito development cycle, the larval period was reduced by four days $(7 \pm 1.2$ days; $\mathrm{P}<0.0001$ ) at a concentration of $100 \mu \mathrm{g} / \mathrm{mL}$ when compared with the testimony control group ( $11 \pm 2$ days). In turn, the L3-adult period was reduced by three days $(10 \pm 1.8$ days; $\mathrm{P}<0.001$ ) (as shown in Table 1(1A)) compared with the testimony control group (13 \pm 1.9 days). The same extract presented 96.7\% $(\mathrm{P}<0.001)$ and $86.7 \%(\mathrm{P}<0.001)$ larval mortality (L3) at concentrations of $200 \mu \mathrm{g} / \mathrm{mL}$ and $100 \mu \mathrm{g} / \mathrm{mL}$, respectively, for up to 48 hours of treatment (as shown in Table 1 (1B)).
This extract revealed an $\mathrm{LC}_{50}$ value of $37.2 \mu \mathrm{g} / \mathrm{mL}$. In addition, bioassays with the AcOEt extract demonstrated larval viability (L3-L4) of only 3.3\% (200 $\mu \mathrm{g} / \mathrm{mL})$ and $13.3 \%$ $(100 \mu \mathrm{g} / \mathrm{mL})$.

At lower concentrations, the AcOEt extract at $50 \mu \mathrm{g} / \mathrm{mL}$ reduced the larval period by four days ( $8.1 \pm 1.7$ days; $\mathrm{P}<0.0001)$ as compared with the control testimony (12.5 \pm 3.1 days) (as shown in Table $2(2 \mathrm{~A})$ ). The time required for $\mathrm{L} 3$-to-adult development showed a reduction at concentrations of $10 \mu \mathrm{g} / \mathrm{mL}(12.9 \pm 2.8$ days; $\mathrm{P}<0.1)$ and $50 \mu \mathrm{g} / \mathrm{mL}$ (10.8 \pm 1.9 days; $\mathrm{P}<0.0001)$, in relation to the control testimony (15.3 \pm 3.3 days) (as shown in Table 2 (2A)). The same extract showed low mortality among L3 larvae at concentrations of $1 \mu \mathrm{g} / \mathrm{mL}$ and $10 \mu \mathrm{g} / \mathrm{mL}(6.7 \%$ and $10 \%$ ), respectively (as shown in Table 2 (2B)). Similarly, mortality was low in the case of L4 larvae (10 and 5\%) (as shown in Table 2 (2B)). At the concentration of $50 \mu \mathrm{g} / \mathrm{mL}$, the extract presented moderate mortality for L3 (40\%) $(\mathrm{P}<0.01)$, but low mortality for L4 and pupae (13.3\% and $3.5 \%$ ), respectively (as shown in Table $2(2 \mathrm{~B})$ ).

Regarding the larval development period, the $\mathrm{MeOH}$ extract at concentration of $200 \mu \mathrm{g} / \mathrm{mL}$ (8.5 \pm 0.9 days; $\mathrm{P}<0.0001)$ reduced the larval period, in comparison with the testimony control (11.8 \pm 1.9 days). Besides, the pupal period at concentrations of $100 \mu \mathrm{g} / \mathrm{mL}(2.1 \pm 0.4$ days; $\mathrm{P}<0.01)$ and $200 \mu \mathrm{g} / \mathrm{mL}(4.5 \pm 2.2$ days; $\mathrm{P}<0.0001)$ were extended when compared with the testimony control group ( $1.7 \pm 0.6$ days) (as shown in Table $3(3 \mathrm{~A})$ ).

Twenty-four hours after treatment, the larvicidal activity of the $\mathrm{MeOH}$ extract of $M$. charantia resulted in low mobility and lethargy among the larvae. Mortality of L3 larvae reached $70 \%(P<0.001)$ at the concentration of $200 \mu \mathrm{g} / \mathrm{mL}$ (as shown in Table 3 (3B)), with $20 \%$ viability $(\mathrm{P}<0.01)$ for $\mathrm{L} 3$-adult development, resulting from larval disintegration and thus reducing the chances of larval emergence. This extract exhibited low toxicity at the concentration of $100 \mu \mathrm{g} / \mathrm{mL}$, with only $1.7 \%$ L3 larval mortality, 10\% L4 larval mortality, and 3.3\% pupal mortality

Table 1. Duration of development (A) and mortality (B) of Aedes aegypti in L3 larvae treated in a rearing environment with crude ethyl acetate extract (AcOEt) from the flowers and fruits of Momordica charantia.

\begin{tabular}{|c|c|c|c|c|c|c|c|c|c|}
\hline \multirow{2}{*}{$\begin{array}{c}\text { Application } \\
1 \mathrm{~A}\end{array}$} & \multicolumn{3}{|c|}{ Larval (days) } & \multicolumn{3}{|c|}{ Pupal (days) } & \multicolumn{3}{|c|}{ L3-Adult (days) } \\
\hline & $\mathrm{X} \pm \mathrm{SD}$ & $\mathbf{R}$ & & $X \pm S D$ & $\mathbf{R}$ & & $X \pm S D$ & $\mathbf{R}$ & \\
\hline Control & $12.2 \pm 2^{\mathrm{a}}$ & $4-15$ & & $1.7 \pm 0.5^{\mathrm{a}}$ & $1-3$ & & $13.5 \pm 1.8^{\mathrm{a}}$ & $5-16$ & \\
\hline Testimony & $11 \pm 2^{\mathrm{b}}$ & $6-14$ & & $2.3 \pm 0.7^{b}$ & $1-4$ & & $13 \pm 1.9^{\mathrm{ab}}$ & $9-15$ & \\
\hline $100 \mu \mathrm{g} / \mathrm{mL}$ & $7 \pm 1.2^{\mathrm{c}^{* * * * *}}$ & $5-8$ & & $2.8 \pm 0.9^{\mathrm{b}}$ & $2-5$ & & $11 \pm 1.8^{\mathrm{c}^{* * *}}$ & $8-13$ & \\
\hline $200 \mu \mathrm{g} / \mathrm{mL}$ & $10 \pm 1.4^{\mathrm{bc}}$ & $9-11$ & & $3 \pm 1.4^{\mathrm{b}}$ & $2-4$ & & $13 \pm 2.8^{\mathrm{ab}}$ & $11-15$ & \\
\hline \multirow{2}{*}{ 1B } & \multicolumn{3}{|c|}{ L3 } & \multicolumn{3}{|c|}{ L4 } & \multicolumn{3}{|c|}{ Pupa } \\
\hline & $X \pm S D$ & $\mathbf{R}$ & $\%$ & $\mathrm{X} \pm \mathrm{SD}$ & $\mathbf{R}$ & $\%$ & $\mathrm{X} \pm$ SD & $\mathbf{R}$ & $\%$ \\
\hline Control & $0 \pm 0^{\mathrm{a}}$ & 0 & 0 & 0 & 0 & 0 & $0.3 \pm 0.5$ & $13-13$ & 1.7 \\
\hline Testimony & $0 \pm 0^{\mathrm{ab}}$ & 0 & 0 & 0 & 0 & 0 & 0 & 0 & 0 \\
\hline $100 \mu \mathrm{g} / \mathrm{mL}$ & $17 \pm 1.0^{\mathrm{c}^{*+*}}$ & $2-7$ & 86.7 & 0 & 0 & 0 & 0 & 0 & 0 \\
\hline $200 \mu \mathrm{g} / \mathrm{mL}$ & $19 \pm 1.0^{\mathrm{d}^{* * *}}$ & $2-5$ & 96.7 & 0 & 0 & 0 & 0 & 0 & 0 \\
\hline
\end{tabular}

Experiments with 20 A. aegypti larvae (L3) for each test and control group were performed in triplicate and with three repetitions. Mean and standard deviation $(\mathrm{X} \pm \mathrm{SD}$ ). Range $(\mathrm{R})$. Values followed by the same letter do not present significant differences. Significance levels through the Tukey test, represented as ${ }^{* * * *} \mathrm{P}<0.0001 ;{ }^{* * *} \mathrm{P}<0.0001$. 
Table 2. Duration of development (A) and mortality (B) of Aedes aegypti in L3 larvae treated in a rearing environment with crude ethyl acetate extract (AcOEt) from the flowers and fruits of Momordica charantia.

\begin{tabular}{|c|c|c|c|c|c|c|c|c|c|}
\hline \multirow{2}{*}{$\begin{array}{c}\text { Application } \\
2 A\end{array}$} & \multicolumn{3}{|c|}{ Larval (days) } & \multicolumn{3}{|c|}{ Pupal (days) } & \multicolumn{3}{|c|}{ L3-Adult (days) } \\
\hline & $X \pm S D$ & \multicolumn{2}{|l|}{$\mathbf{R}$} & $X \pm S D$ & \multicolumn{2}{|l|}{$\mathbf{R}$} & $X \pm S D$ & \multicolumn{2}{|l|}{$\mathbf{R}$} \\
\hline Control & $11.7 \pm 4.8^{\mathrm{a}}$ & \multicolumn{2}{|l|}{$2-23$} & $2.8 \pm 0.7^{\mathrm{a}}$ & \multicolumn{2}{|l|}{$1-5$} & $14.4 \pm 4.9^{\mathrm{a}}$ & \multicolumn{2}{|c|}{$5-25$} \\
\hline Testimony & $12.5 \pm 3.1^{\mathrm{ab}}$ & \multicolumn{2}{|l|}{$7-19$} & $2.9 \pm 0.6^{\mathrm{ab}}$ & \multicolumn{2}{|l|}{$2-4$} & $15.3 \pm 3.3^{\mathrm{ab}}$ & \multicolumn{2}{|c|}{$9-22$} \\
\hline $1 \mu \mathrm{g} / \mathrm{mL}$ & $13.1 \pm 4.4^{\mathrm{ab}}$ & \multicolumn{2}{|l|}{$5-22$} & $2.4 \pm 0.8^{\mathrm{ac}^{*}}$ & \multicolumn{2}{|l|}{$1-4$} & $15.7 \pm 4.5^{\mathrm{ab}}$ & \multicolumn{2}{|l|}{$8-24$} \\
\hline $10 \mu \mathrm{g} / \mathrm{mL}$ & $10 \pm 1.9^{a c^{* *}}$ & \multicolumn{2}{|l|}{$7-15$} & $3 \pm 1.5^{\mathrm{ab}}$ & \multicolumn{2}{|l|}{$1-9$} & $12.9 \pm 2.8^{\mathrm{ac}^{*}}$ & \multicolumn{2}{|c|}{$8-21$} \\
\hline $50 \mu \mathrm{g} / \mathrm{mL}$ & $8.1 \pm 1.7^{c^{n+n+t}}$ & \multicolumn{2}{|l|}{$5-11$} & $2.6 \pm 0.8^{\mathrm{ab}}$ & \multicolumn{2}{|l|}{$1-4$} & $10.8 \pm 1.9^{\mathrm{d}^{\mathrm{s} * * *}}$ & \multicolumn{2}{|l|}{ 8-14 } \\
\hline \multirow{2}{*}{ 2B } & \multicolumn{3}{|c|}{ L3 } & \multicolumn{3}{|c|}{ L4 } & \multicolumn{3}{|c|}{ Pupa } \\
\hline & $\mathrm{X} \pm \mathrm{SD}$ & $\mathbf{R}$ & $\%$ & $X \pm S D$ & $\mathbf{R}$ & $\%$ & $X \pm S D$ & $\mathbf{R}$ & $\%$ \\
\hline Control & $0.3 \pm 0.5^{\mathrm{a}}$ & $1-1$ & 3.3 & $0.3 \pm 0.5^{\mathrm{a}}$ & $1-1$ & 1.7 & $0.3 \pm 0.5^{\mathrm{a}}$ & $1-1$ & 1.7 \\
\hline Testimony & $0.3 \pm 0.5^{\mathrm{ab}}$ & $1-1$ & 1.7 & $0^{\mathrm{a}}$ & $0-0$ & 0 & $1 \pm 0^{\mathrm{a}}$ & $1-1$ & 5 \\
\hline $1 \mu \mathrm{g} / \mathrm{mL}$ & $1 \pm 1^{\mathrm{ab}}$ & $1-3$ & 6.7 & $2 \pm 2^{\mathrm{a}}$ & $1-4$ & 10 & $0^{\mathrm{a}}$ & 0 & 0 \\
\hline $10 \mu \mathrm{g} / \mathrm{mL}$ & $2 \pm 3^{\mathrm{ab}}$ & $1-5$ & 10 & $1.2 \pm 1^{\mathrm{a}}$ & $1-2$ & 5 & $0.3 \pm 0.5^{\mathrm{a}}$ & $1-1$ & 2 \\
\hline $50 \mu \mathrm{g} / \mathrm{mL}$ & $8 \pm 44^{c^{* *}}$ & $3-12$ & 40 & $3 \pm 0.5^{\mathrm{a}}$ & $2-3$ & 13.3 & $0.3 \pm 0.5^{\mathrm{a}}$ & $1-1$ & 3.5 \\
\hline
\end{tabular}

Experiments with 20 A. aegypti larvae (L3) for each test and control group were performed in triplicate and with three repetitions. Mean and standard deviation $(\mathrm{X} \pm \mathrm{SD})$. Range $(\mathrm{R})$. Values followed by the same letter do not present significant differences. Significance levels through the Tukey test, represented as ${ }^{* * * *} \mathrm{P}<0.0001 ;{ }^{* *} \mathrm{P}<0.01 ;{ }^{*} \mathrm{P}<0.1$ vs testimony control AcOEt:DMSO $(1: 3)$.

Table 3. Duration of the development (A) and mortality (B) of Aedes aegypti in L3 larvae treated in a rearing environment with crude methanol $(\mathrm{MeOH})$ extract from the flowers and fruits of Momordica charantia.

\begin{tabular}{|c|c|c|c|c|c|c|c|c|c|}
\hline \multirow{2}{*}{$\begin{array}{c}\text { Application } \\
3 \mathrm{~A}\end{array}$} & \multicolumn{3}{|c|}{ Larval (days) } & \multicolumn{3}{|c|}{ Pupal (days) } & \multicolumn{3}{|c|}{ L3-Adult (days) } \\
\hline & $X \pm S D$ & $\mathbf{R}$ & & $X \pm S D$ & $\mathbf{R}$ & & $X \pm S D$ & $\mathbf{R}$ & \\
\hline Control & $13.2 \pm 1.9^{a}$ & $5-16$ & & $1.7 \pm 0.6^{\mathrm{a}}$ & $1-3$ & & $14.5 \pm 1.8^{\mathrm{a}}$ & $6-17$ & \\
\hline Testimony & $11.8 \pm 1.9^{\mathrm{b}}$ & $6-14$ & & $1.6 \pm 0.6^{b}$ & $1-4$ & & $13.5 \pm 1.8^{\mathrm{b}}$ & $7-16$ & \\
\hline $100 \mu \mathrm{g} / \mathrm{mL}$ & $11.2 \pm 1.9^{\mathrm{b}}$ & $7-13$ & & $2.1 \pm 0.4 \mathrm{c}^{* *}$ & $2-4$ & & $13.4 \pm 1.7^{\mathrm{b}}$ & $9-15$ & \\
\hline $200 \mu \mathrm{g} / \mathrm{mL}$ & $8.5 \pm 0.9^{\mathrm{c}^{* * * *}}$ & $7-11$ & & $4.5 \pm 2.2^{\mathrm{d}^{*+* *+}}$ & $1-7$ & & $13 \pm 2.5^{b}$ & $9-15$ & \\
\hline \multirow{2}{*}{ 3B } & \multicolumn{3}{|c|}{ L3 } & \multicolumn{3}{|c|}{ L4 } & \multicolumn{3}{|c|}{ Pupa } \\
\hline & $X \pm S D$ & $\mathbf{R}$ & $\%$ & $X \pm S D$ & $\mathbf{R}$ & $\%$ & $X \pm S D$ & $\mathbf{R}$ & $\%$ \\
\hline Control & $0^{\mathrm{a}}$ & 0 & 0 & $0^{\mathrm{a}}$ & 0 & 0 & $0.3 \pm 0.5^{\mathrm{a}}$ & $13-13$ & 1.7 \\
\hline Testimony & $0^{\mathrm{ab}}$ & 0 & 0 & $0^{\mathrm{ab}}$ & 0 & 0 & $0^{\mathrm{ab}}$ & 0 & 0 \\
\hline $100 \mu \mathrm{g} / \mathrm{mL}$ & $0.3 \pm 0.5^{\mathrm{ab}}$ & $1-1$ & 1.7 & $2 \pm 3^{\mathrm{ab}}$ & $6-6$ & 10 & $0.3 \pm 0.5^{\mathrm{ab}}$ & $1-1$ & 3.3 \\
\hline $200 \mu \mathrm{g} / \mathrm{mL}$ & $13 \pm 4^{\mathrm{c}^{* * *}}$ & $1-6$ & 70 & $1 \pm 0^{\mathrm{ab}}$ & $1-2$ & 8.3 & $1 \pm 1^{\mathrm{ab}}$ & $2-2$ & 1.7 \\
\hline
\end{tabular}

Experiments with 20 Ae. aegypti larvae (L3) for each test and control group were performed in triplicate and with three repetitions. Mean and standard deviation $(\mathrm{X} \pm \mathrm{SD})$. Range $(\mathrm{R})$. Values followed by the same letter do not present significant differences. Significance levels through the Tukey test, represented as ${ }^{* * * *} \mathrm{P}<0.0001 ;{ }^{* * *} \mathrm{P}<0.001$; ${ }^{* *} \mathrm{P}<0.01$ vs testimony control MeOH:DMSO (1:3).

(as shown in Table $3(3 \mathrm{~B})$ ). Furthermore, the MeOH extract presented $\mathrm{LC}_{50}=129.6 \mu \mathrm{g} / \mathrm{mL}$.

The results indicated that the HEX crude extract showed low larval toxicity at a concentration of $100 \mu \mathrm{g} / \mathrm{mL}$ and resulted in 78-90\% larval emergence. Considering the development period, these results were statistically similar to those obtained from the testimony control group.

\section{Discussion}

Diseases transmitted by mosquitoes are a threat to human health. There are many strategies to control mosquitoes like A. aegypti and its immatures forms (Brasil, 2009). However, the synthetic chemical insecticides currently in use have some disadvantages. Some factors such as vector resistance, toxicity to humans and non-target organisms drive the interest in exploring new control alternatives (Pavela, 2016; Benelli, 2018).

Plants are rich sources of resource for biologically active substances that show a potential to control $A$. aegypti, being considered attractive alternatives to the conventional chemical insecticides (Muangmoon et al., 2018).

In some regions of Africa, plant-based methods such as burning raw materials, crude extracts, and oil preparations have demonstrated repellency against mosquitoes and 
provided protection for humans. In rural communities, these traditional methods are accessible and easily available (Pavela and Benelli, 2016). Many studies have documented the effectiveness of plant extracts and their isolated substances in controlling A. aegypti. In this context, Azevedo et al. (2019) evaluated the larvicidal activity of extracts from 16 native plants from the Araripe National Forest, Ceará, Brazil. Among the plants that were evaluated, the ethanolic extract of Ocotea sp. was the most efficient against $A$. aegypti, presenting $100 \%$ larval mortality in all tested concentrations. In a study conducted by Cruz et al. (2019), the steroidal alkaloid solasodine, isolated from the fruit of Solanum paludosum, caused $63 \%$ mortality of the $4^{\text {th }}$ instar larvae at a concentration of $150 \mu \mathrm{g} / \mathrm{mL}$.

Regarding the insecticidal activity of $M$. charantia, Pari et al. (2020) studied the activity of the ethanolic extract of $M$. charantia seed against the immature forms of An. stephensi, C. quinquefasciatus and A. aegypti and the results in the third instar showed $\mathrm{LD}_{50}=246.757 \mathrm{ppm}$, $\mathrm{LD}_{50}=239.018 \mathrm{ppm}$ and $\mathrm{LD}_{50}=228.001 \mathrm{ppm}$, respectively.

Singh et al. (2006) reported that this plant revealed larvicidal activity against three mosquito species: An. stephensi, C. quinquefasciatus and A. aegypti. Maurya et al. (2009) evaluated the larvicide activity of M. charantia fruit against An. stephensi and C. quinquefasciatus in petroleum ether, carbon tetrachloride and methanol extracts. The methanol extract presented activity against An. stephensi $\left(\mathrm{LD}_{50}=142.82 \mu \mathrm{g} / \mathrm{mL}, \mathrm{LD}_{90}=524.54 \mu \mathrm{g} / \mathrm{mL}\right)$ and against $C$. quinquefasciatus $\left(\mathrm{LD}_{90}=579.93 \mu \mathrm{g} / \mathrm{mL}\right)$. This means that higher concentrations of the methanol extract of $M$. charantia fruit would produce a more potent larvicidal activity, as demonstrated by the study conducted by Subramaniam et al. (2012), where the larvicide activity of $M$. charantia leaves was tested against An. stephensiin the four larval and pupal stages. They found different activities for the methanol extract between the various stages: $1^{\text {st }}$ instar, $\mathrm{LD}_{50}=93.45 \mu \mathrm{g} / \mathrm{mL} ; 2^{\text {nd }}$ instar, $\mathrm{LD}_{50}=123.74 \mu \mathrm{g} / \mathrm{mL}$; $3^{\text {rd }}$ instar, $\mathrm{LD}_{50}=167.17 \mu \mathrm{g} / \mathrm{mL} ; 4^{\text {th }}$ instar, $\mathrm{LD}_{50}=216.15 \mu \mathrm{g} / \mathrm{mL}$; and pupae, $\mathrm{LD}_{50}=256.66 \mu \mathrm{g} / \mathrm{mL}$. Methanol extract at a concentration of $100 \mu \mathrm{g} / \mathrm{mL}$ presented low toxicity, while at $200 \mu \mathrm{g} / \mathrm{mL}$ a moderate toxicity was observed. Similar data were obtained from Rahuman and Venkatesan (2008) working with the Cucurbitaceae family, who have demonstrated the existence of larvicide activity against fourth-stage $A$. aegypti larvae with a methanol extract $\left(\mathrm{LD}_{50}=199.14 \mu \mathrm{g} / \mathrm{mL}, \mathrm{LD}_{90}=780.10 \mu \mathrm{g} / \mathrm{mL}\right)$, although in the current study an LD 50 was obtained at a lower concentration.

Kamaraj and Rahuman (2010) found that ethyl acetate extract from the leaves of five plant species of the family Cucurbitaceae which were tested, including M. charantia, produced high mortality (L4) at a concentration of $500 \mu \mathrm{g} / \mathrm{mL}$ against Culex gelidus and $C$. quinquefasciatus. This result was similar to that of the present study regarding the ethyl acetate extract from $M$. charantia flowers and fruits at concentrations of $100 \mu \mathrm{g} / \mathrm{mL}$ and $200 \mu \mathrm{g} / \mathrm{mL}$ (87\% and $97 \%$, respectively). It is important to note that the ethyl acetate extract of flowers and fruits showed the same activity at lower concentrations.

On the other hand, the hexane extract of $M$. charantia did not show toxicity for L3 larvae and only a low toxicity for L4 larvae and pupae was observed. According to the work reported by Kamaraj and Rahuman (2010), the hexane extract presented low toxicity against $C$. gelidus and C. quinquefasciatus. Singh et al. (2006) demonstrated that the hexane extract of $M$. charantia fruits had better larvicidal activity than the crude aqueous extract, and that An. stephensi larvae were more susceptible than C. quinquefasciatus and A. aegypti larvae. The difference in results can be explained based on the chemical composition of plants which may vary according to environmental factors such as soil type, humidity, solar irradiation, wind, temperature and atmospheric pollution, among others (Barreto, 2005).

The ethyl acetate extract of $M$. charantia demonstrated toxicity against $A$. aegypti larvae, thus confirming the efficacy of this species of the Cucurbitaceae family as a source of active natural plant products and its importance as a potential new larvicide for controlling the mosquito vector of dengue virus, zika, chikungunya, and urban yellow fever.

\section{Acknowledgements}

This study was financed in part by the Coordenação de Aperfeiçoamento de Pessoal de Nível Superior-Brasil (CAPES) - Finance Code 001. The Fundação de Amparo à Pesquisa do Estado do Rio de Janeiro (FAPERJ) contributed for its financial and scientific support with the project entitled "Novas estratégias para o controle do mosquito Aedes aegypti, vetor da Dengue, Chikungunya e do vírus Zika: uma abordagem integrada/RedeZIKA\#1). The authors are also grateful to Núcleo Operacional Sentinela de Mosquitos Vetores (Nosmove), Oswaldo Cruz Institute, FIOCRUZ, Rio de Janeiro, Brazil; FUSVE/Universidade de Vassouras, Centro de Ensino Superior de Valença, and Fundação Educacional Dom André Arcoverde (CESVA/FAA).

\section{References}

AZEVEDO, F.R., MACIEL, G.C., OLIVEIRA, G.B.S., MESQUITA, F.O. and ALVES, A.C.L., 2019. Larvicidal activity of native plant extracts from the Araripe National Forest on Aedes aegypti. The Journal of Agricultural Science, vol. 11, no. 7, pp. 105.

BARRETO, C.F., 2005. Aedes aegypti-Resistência aos inseticidas químicos e as novas alternativas de controle. Revista Eletrônica Faculdade Montes Belos, vol. 2, no. 1, pp. 62-73.

BENELLI, G., 2018. Mode of action of nanoparticles against insects. Environmental Science and Pollution Research International, vol. 25, no. 13, pp. 12329-12341. http://dx.doi.org/10.1007/s11356018-1850-4. PMid:29611126.

BEZERRA, F.P., AGUIAR, R.W.S., CARVALHO, E.E.N., BORGES, J.C.M. and VALE, B.N., 2014. Jatropha curcas L. (Euphorbiaceae) como novo bioinseticida: análise fitoquímica preliminar e atividade larvicida contra Aedes aegypti (Diptera: Culicidae). Revista Amazônia Science E Health, vol. 2, no. 3, pp. 17-25.

BRASIL. Ministério da Saúde. Secretaria de Vigilância em Saúde, 2009. Diretrizes Nacionais Para a Prevenção e Controle de Epidemias de Dengue, Normas e Manuais Técnicos. Brasília: Ministério da Saúde, Secretaria de Vigilância em Saúde. Série A. 
CRUZ, I.L.S., PARDAL, B.M., ALVES, S.P., MEDEIROS, G.A.M., BARBOSAFILHO, J.M. and MALECK, M., 2019. Alcaloide esteroidal, substância de Solanum paludosum, com atividade larvicida sobre Aedes aegypti. Revista de Saúde, vol. 10, no. 1, pp. 15-19.

DUTRA, R.C., CAMPOS, M.M., SANTOS, A.R. and CALIXTO, J.B., 2016. Medicinal plants in Brazil: pharmacological studies, drug discovery, challenges and perspectives. Pharmacological Research, vol. 112, pp. 4-29. http://dx.doi.org/10.1016/j.phrs.2016.01.021. PMid:26812486.

FORMENTINI, M.A., ALVES, L.F.A. and SCHAPOVALOFF, M.E., 2016. Insecticidal activity of neem oil against Gyropsylla spegazziniana (Hemiptera: Psyllidae) nymphs on Paraguay tea seedlings. Brazilian Journal of Biology = Revista Brasileira de Biologia, vol. 76, no. 4, pp.951954. http://dx.doi.org/10.1590/1519-6984.04915. PMid:27143053.

GOULD, E., PETTERSSON, J., HIGGS, S., CHARREL, R. and DE LAMBALLERIE, X., 2017. Emerging arboviruses: why today? One Health, vol. 4, pp. 1-13. http://dx.doi.org/10.1016/j. onehlt.2017.06.001. PMid:28785601.

HAMILTON, M.A., RUSSO, R.C. and THURSTON, R.V., 1977. Trimmed Sperman-Karber method for estimating median lethal concentrations in toxicity bioassays. Environmental Science E Technology, vol. 11, no. 7, pp. 714-719. http://dx.doi. org/10.1021/es60130a004.

JIA, S., SHEN, M., ZHANG, F., and XIE, J., 2017. Recent advances in Momordica charantia: functional components and biological activities. International Journal of Molecular Sciences, vol. 18, vol. 12, pp. 2555

KAMARAJ, C. and RAHUMAN, A.A., 2010. Larvicidal and adulticidal potential of medicinal plant extracts from south India against vectors. Asian Pacific Journal of Tropical Medicine, vol. 3, no. 12, pp. 948-953. http://dx.doi.org/10.1016/S1995-7645(11)60006-0.

MALECK, M., SANTOS, F.C.C., SERDEIRO, M.T., GUIMARÃES, A.E., FERREIRA, B., GUNAYDIN, K. and ALMEIDA, A.P., 2013. Kellin: a furanochromone with toxicity against Oncopeltus fasciatus (Hemiptera) and Aedes aegypti (Diptera). Jundishapur Journal of Natural Pharmaceutical Products, vol. 4, no. 1, pp. 32-36.

MAURYA, P., SHARMA, P., MOHAN, L., BATABYAL, L. and SRIVASTAVA, C.N., 2009. Evaluation of larvicidal nature of fleshy fruit wall of Momordica charantia Linn. (Family: Cucurbitaceae) in the management of mosquitoes. Parasitology Research, vol. 105, no. 6, pp. 1653-1659. http://dx.doi.org/10.1007/s00436-009-1609-4. PMid:19760435.

MENDONÇA, F.A., SOUZA, A.V. and DUTRA, D.A., 2009. Saúde Pública, Urbanização e Dengue no Brasil. Sociedade E Natureza, vol. 21, no. 3, pp. 257-269. http://dx.doi.org/10.1590/S198245132009000300003.

MUANGMOON, R., JUNKUM, A., CHAITHONG, U., JITPAKDI, A., RIYONG, D., WANNASAN, A., SOMBOOM, P. and PITASAWAT, B., 2018. Natural larvicides of botanical origin against dengue vector Aedes aegypti (Diptera: culicidae). The Southeast Asian Journal of Tropical Medicine and Public Health, vol. 49, no. 2, pp. 227-239.

NAQQASH, M.N., GOKÇE, A., BAKHSH, A. and SALIM, M., 2016. INSECTICIDE RESISTANCE AND ITS MOLECULAR BASIS IN URBAN INSECT PESTS. Parasitology Research, vol. 115, no. 4, pp. 1363-1373. http://dx.doi.org/10.1007/s00436-015-4898-9 PMid:26758450.

PANCHAL, K. and TIWARI, A.K., 2017. Drosophila melanogaster “a potential model organism" for identification of pharmacological properties of plants/plant-derived components. Biomedicine and Pharmacotherapy, vol. 89, pp. 1331-1345. http://dx.doi. org/10.1016/j.biopha.2017.03.001. PMid:28320100.

PARI, M., ARJUNAN, N., SUBRAMANI, U., RAMASAMY, V., KADARKARAI, M., and CHINNATHAMBI, V., 2020. Water purification and larvicidal activity of seed extract, Momordica charantia. GSC Advanced Research and Reviews, vol. 2, no. 1, pp. 001-009. https://doi.org/10.30574/gscarr.2020.2.1.0001.

PAVELA, R. and BENELLI, G., 2016. Ethnobotanical knowledge on botanical repellents employed in the African region against mosquito vectors - A review. Experimental Parasitology, vol. 167, pp. 103-108. http://dx.doi.org/10.1016/j.exppara.2016.05.010. PMid:27260568.

PAVELA, R., 2016. History, presence and perspective of using plant extracts as commercial botanical insecticides and farm products for protection against insects - a review. Plant Protection Science, vol. 52, no. 4, pp. 229-241. http://dx.doi. org/10.17221/31/2016-PPS.

RAHUMAN, A.A. and VENKATESAN, P., 2008. Larvicidal efficacy of five cucurbitaceous plant leaf extracts against mosquito species. Parasitology Research, vol. 103, no. 1, pp. 133-139. http://dx.doi. org/10.1007/s00436-008-0940-5. PMid:18340464.

SINGH, R.K., DHIMAN, R.C. and MITTAL, P.K., 2006. Mosquito Larvicidal Properties of Momordica charantia Linn (Family: cucurbitaceae). Journal of Vector Borne Diseases, vol. 43, no. 2, pp. 88-91. PMid:16967822.

SOKAL, R.R. and ROHLF, F.J., 1979. Biometria: principios y métodos estadísticos en la investigación biológica. Madri: H. Blume Ediciones. $832 \mathrm{p}$.

SPOCHACZ, M., CHOWA-SKI, S., WALKOWIAK-NOWICKA, K., SZYMCZAK, M. and ADAMSKI, Z., 2018. Plant-derived substances used against beetles-pests of stored crops and food-and their mode of action: a review. Comprehensive Reviews in Food Science and Food Safety, vol. 17, no. 5, pp. 1339-1366. http://dx.doi. org/10.1111/1541-4337.12377. PMid:33350162.

SUBRAMANIAM, J., MURUGAN, K. and KOVENDAN, K., 2012. Larvicidal and pupcidal efficacy of Momordica charantia leaf extract and bacterial insecticide, Bacillus thuringiensis against malarial vector, Anopheles stephensi Liston. (Diptera: culicidae). Journal of Biopesticides, vol. 5, pp. 163-169.

WORLD HEALTH ORGANIZATION - WHO, 2005 [viewed 28 July 2015]. Guidelines for laboratory and field testing of Mosquito Larvicides [online]. Geneva: WHO. Available from: http://www. who.int/iris/handle/10665/69101

ZOCOLER, A.M.D., MOURÃO, K.S.M., MELLO, J.C.P. and MARQUES, L.C., 2006. Contribuição ao Controle de Qualidade Farmacognóstico das Folhas e Caules de Melão-de-São Caetano (Momordica charantia L. - Cucurbitaceae). Latin American Journal of Pharmacy, vol. 25 , no. 1, pp. 22-27. 